\title{
A Comparison of the Korean and Japanese Approaches to Foreign Family Names
}

\author{
JIN Guanglin*
}

\begin{abstract}
There are many foreign family names in Korean and Japanese genealogies. This paper is especially focused on the fact that out of approximately 280 Korean family names, roughly half are of foreign origin, and that out of those foreign family names, the majority trace their beginnings to China. In Japan, the Newly Edited Register of Family Names (新撰姓氏錄), published in 815, records that out of 1,182 aristocratic clans in the capital and its surroundings, 326 clans - approximately one-third - originated from China and Korea. Does the prevalence of foreign family names reflect migration from China to Korea, and from China and Korea to Japan? Or is it perhaps a result of Korean Sinophilia (慕華思想) and Japanese admiration for Korean and Chinese cultures? Or could there be an entirely distinct explanation? First I discuss premodern Korean and ancient Japanese foreign family names, and then I examine the formation and characteristics of these family names. Next I analyze how migration from China to Korea, as well as from China and Korea to Japan, occurred in their historical contexts. Through these studies, I derive answers to the above-mentioned questions.
\end{abstract}

Key words: family names (surnames), Chinese-style family names, cultural diffusion and adoption, migration, Sinophilia in traditional Korea and Japan

\section{Foreign Family Names in Premodern Korea}

The precise number of Korean family names varies by record. The Geography Annals of King Sejong (世宗實錄地理志, 1454), the first systematic register of Korean family names, records 265 family names, but the Survey of the Geography of Korea (東國舆地勝覽, 1486) records 277. In the 1930 census, 250 family names are recorded, while the South Korean census of 2000 docu-

* Professor, Niigata Sangyo University 
ments 286 family names, along with 4,179 ancestral seats (pon'gwan, 本貫). ${ }^{1}$ The ancestral seat refers to the birthplace of the putative apical ancestor (始 祖) or the founder (中始祖) of the family name. It can also refer to the area considered to be the clan's hometown. Even within a family of the same name, a clan's expansion and development can bring about a new ancestral seat. In South Korea today, there are ten times more ancestral seats than the number of family names.

About half of Korea's 280 or so family names originate from outside of the Korean peninsula (according to a 1985 study, 136 out of 275 Korean family names were categorized as foreign surnames), and among those names, the majority are from China. ${ }^{2}$

In the following sections, I will present how foreign family names arrived in premodern Korea in each historical period.

\subsection{Names of Foreign Families Descended from Kija}

Four clans claim to be directly related to Kija (Jizi in Chinese, 箕子), and several other clans claim to be the descendants of those who followed Kija from China. Kija is a mythical figure said to have been a Shang (商) aristocrat. He is recorded in such Chinese texts as the Great Commentary on the Book of Documents (晌書大傳), Records of the Grand Historian (史記), and the “Treatise on Geography" in the History of the Former Han Dynasty (漢書, 地 理誌). While Kija's kingdom was called Kija Chosŏn (箕子朝鮮) in premodern Korea, nowadays it is considered to be more legendary than historic fact. The following are the four clans that purport to be descended from Kija.

Ch'ŏngju-Han clan (清州韓氏) The Ch'ŏngju-Han clan is said to originate from Kija's descendant Urang (友諒). The thirty-second descendant of Urang, an early Koryŏ (高麗, 918-1392) figure by the name of Han Ra (韓蘭, 853-916), is the founder of the Ch'ongju-Han clan. According to Ch'ŏngju-Han genealogical records, the last king of Kija Chosŏn, Jun (準), had three sons by the name of Usŏng (友誠), Upyŏng (友平), and Urang (友 諒). It is said that the Haengju-Ki clan (幸州奇氏), T'aewŏn-Sŏnwu clan (太原 鮮于氏), and Ch'ŏngju-Han clan (清州韓氏) originated from those three sons, respectively.

Haengju-Ki clan (幸州奇氏) In An Augmented Reference of Documents on

1 Yi Su-gŏn 2003, pp.339-351. Ch'oe Tŏk-gyo and Yi Sŭng-u 1985, pp. 22-27. "The Historical Development of Korean Family Names," in Doopedia (http:// www.doopedia.co.kr/).

2 Kim Chŏn-ho 2003, pp. 136-140. 
Korea (增補文獻備考), the apical ancestor of the Haengju-Ki clan is said to have been Ki Usŏng (箕友誠), the forty-eighth descendant of Kija. This record states that when Wiman (衛滿) of the state of Yan (燕國) usurped the throne of Kija Chosŏn in 194 BCE, Ki Jun (箕潐), its last king, fled south and became the king of Han (韓). Ki U-sŏng is said to have descended from Ki Jun. The founder of the Haengju-Ki clan was an early-twelfth-century Koryŏ dynasty figure named Ki Munyu (奇文儒).

T'aewŏn-Sŏnwu clan (太原鮮于氏) In An Augmented Reference of Documents on Korea, a descendant of the king of Mahan (馬韓) is recorded to have given rise to the T'aewŏn-Sŏnwu clan. In the genealogical records of the T'aewŏn-Sŏnwu clan, Sŏnwu Jŏng (鮮于靖), a man who lived during the reign of King Kojong (高宗, r. 1213-1259) of Koryŏ, is said to be the founder.

Ich'ŏn-Š clan (利川徐氏) In An Augmented Reference of Documents on Korea, the Ich'ŏn-Sŏ clan is said to have descended from Kija, and its apical ancestor is said to have been Ki Jun (箕準), the last king of Kija Chosŏn. The founder of the Ich'ŏn-Sŏ clan was Shin'il (神逸) of Unified Silla (統一新羅, 668-935). Among the many ancestral seats of the So clan, many were originally associated with the Ich'ŏn-Sŏ clan.

Besides these family names, the Hamyŏl-Namgung clan (咸悦南宮氏), T'aean-Kyŏng clan (泰安景氏), Ponghwa-Kŭm clan (奉化琴氏), Miryang-No clan (密陽魯氏), T'osan-Kung clan (兔山宮氏), and others are said to descend from followers of Kija. The founders of these five clans were all men of the Koryŏ dynasty.

\subsection{Foreign Family Names from the Han Dynasty}

Though not many Korean clans claim to have originated from the Han dynasty (漢朝, $206 \mathrm{BCE}-220 \mathrm{CE}$ ), the following are some examples:

Kŭngsŏng-Na clan (錦城羅氏) The clan's apical ancestor is said to have come to Korea during the reign of Emperor Gaozu (高祖, r.202-195 BCE) of the Western Han dynasty (西漢). The founder of the Kŭngsŏng-Na clan was $\mathrm{Na}$ Ch'ongrye (羅總禮) of the early Koryŏ period.

Kosŏng-Lee clan (固城李氏) The Kosŏng-Lee clan is said to have descended from Li Pan (李槃), who came to Korea by way of the invasion of Wiman Chosŏn (衛滿朝鮮) by Emperor Wu of the Han (漢武帝) in 108 BCE. The founder was Li Huang (李璜), who is said to be Li Pan's twenty-fourth descendant and who lived during the reign of King T’ŏkjong (德宗, r. 1016- 
1034) of the Koryŏ dynasty.

Huang clan (黃氏) Huang Luo (黃洛), who drifted into Silla (57 BCE-935 CE) while heading to Vietnam as an envoy of Emperor Guangwu (光武帝, r. 25-57) of the Han, is said to have been the apical ancestor of the Huang clan. Several ancestral seats claim to descend from Huang Luo, but the founders of those ancestral seats, with the exception of one who lived during the late Unified Silla period, were all men of the Koryŏ dynasty.

\subsection{Foreign Family Names in the Three Kingdoms and Unified Silla Periods}

There are many clans that claim to have come from China during the Three Kingdoms (三國時代, 1st cent. BCE-7th cent.) and Unified Silla periods. Of those, the majority are said to have come to Korea during the Unified Silla period. The following is a list of clans that came from China during the Three Kingdoms and Unified Silla periods: the Andong-Chang clan (安東張氏), Andong-Son clan (安東孫氏), Ap'hae-Chŏng clan (押海丁氏), Changhŭng-Wi clan (長興魏氏), Chindo-Kim clan (珍島金氏), Chinju-Hyŏn clan (晋州邢氏), Ch'ogye-Pyŏn clan (草溪下氏), Chuksan-An clan (竹山安氏), Ch'ungju-Ch'oe clan (忠州崔氏), Haeju-O clan (海州吳氏), Haengju-Ǔn clan (幸州殷氏), Hamyang-Yŏ clan (咸陽呂氏), Haep'yŏng-Kil clan (海平吉氏), Hyoryŏng-Sagong clan (孝令司空氏), Kwangju-No clan (光州盧氏), Musong-Yu clan (茂松座氏), Namyang-Hong clan (南陽洪氏), Namyang-Pang clan (南陽房 氏), Namyang-Sŏ clan (南陽徐氏), Okchŏn-Ryuk clan (沃川陸氏), Onyang-Pang clan (溫陽方氏), P'aju-Yŏm clan (坡州廉氏), P'unggi-Chin clan (豊基秦氏), Pyŏnghae-Ku clan (平海具氏), Pyŏnt'aek-Im clan (平澤任氏), Sangju-Chu clan (佮州周氏), Sinch’ŏn-Kang clan (信川康氏), Sinchang-Maeng clan (新昌孟氏), Suwŏn-Paek clan (水原白氏), Ǔiryŏng-Nam clan (宜寧南氏), Ǔiryŏn-Ok clan (宜寧玉氏), Wŏnju-Wŏn clan (原州元氏), Yŏnan-Lee clan (延安李氏), Yŏngch’ŏn-Hwangbo clan (永川皇甫氏), Yŏngwŏl-Ŏm clan (寧越嚴氏), etc.

The putative apical ancestors of the clans above came to Silla for various reasons. Some were scholars dispatched by the Tang dynasty (唐朝, 618-907) to Koguryŏ (高句麗, 37? BCE-668 CE) and Silla, others were a part of the Silla-Tang Allied Forces (羅唐聯合軍) against Paekche (百濟, 18? BCE-660 CE) and came to settle in Silla, and still others migrated to Silla to flee from the An Lushan (安祿山之亂, 755-763) and Huangchao (黄巢之亂, 875-884) rebellions. Some fled to Silla during the chaos of the Five Dynasties and Ten Kingdoms Period (五代十國, 902-979), and some others drifted into Silla on the way to Japan as envoys of the Tang dynasty. Over ten clans claim to have descended from the Eight Scholars (八學士), who were dispatched to Silla and Koguryŏ from Tang. 
Most of the founders of the clans mentioned above were men of the Koryŏ period. Only a few date to the Silla period. Few clans have clear records that detail the relations between the putative apical ancestor and the founder. Hence, even where the founder of a clan was a historical figure, it is often difficult to demonstrate the connection between the clan founder and the putative apical ancestor. Here are a few examples of such clans:

Yŏnan-Lee clan (延安李氏) Li Mao (李茂), who served as a Tang general in the 660 attack on Paekche, is said to have settled in Silla afterwards. The Yŏnan-Lee clan later divided into ten different branches, the founders of which were all Koryŏ dynasty figures.

Kwangju-No clan (光州盧氏) Lu Sui (盧穗) came to Silla with his children to flee the An Lushan Rebellion (安祿山之亂) in 755 and subsequently became the putative apical ancestor of the Kwangju-No clan. The Kwangju-No later divided into two branches, the founders of which were both Koryŏ dynasty figures.

Suwŏn-Paek clan (水原白氏) The apical ancestor of the Suwŏn-Paek clan is said to have been a Suzhou (蘇州) man by the name of Yu Jing (宇經), who came to Silla in 780 and became an official. The Suwŏn-Paek consider the late Unified Silla official Chang Jik (昌稷) as their founder.

Ǔiryŏng-Nam clan (宜寧南氏) In 786, during the reign of the Tang emperor Xuanzong (玄宗), Jin Zhong (金忠) was dispatched to Japan as an envoy, and on route he encountered a typhoon and drifted to Silla. The Silla king bestowed upon him the Nam family name. The founder of the Üiryŏng-Nam clan was Nam Kunbo (南君甫), a Koryŏ dynasty figure.

Chuksan-An clan (竹山安氏) The Tang man Li Yuan (李瑗) came to Silla in 807 , and his three sons were bestowed the An family name by the Silla king for having pacified Japanese pirates (倭寇). They subsequently settled in Silla. The Chuksan-An clan was divided into two branches, the founders of which were both Koryŏ dynasty figures.

Namyang-Hong clan (南陽洪氏) Hong Tianhe (洪天河) is said to have been the apical ancestor of the Namyang-Hong. A Tang scholar who was dispatched to Koguryŏ, he fled domestic turmoil in Koguryŏ and settled in Silla. The founder of the Namyang-Hong clan was Hong Ǔnyŏl (洪殷悅), a meritorious subject who appears in the History of Koryŏ (高麗史). 
Haengju-Ǔn clan (幸州殷氏) Yin Hongyue (殷洪悅), a scholar sent to Silla in 850 , is said to have been the apical ancestor of this clan. The founder of the Haengju-Ǔn lived during the reign of King Kojong (高宗, r. 1213-1259) of the Koryŏ dynasty.

Okchŏn-Ryuk clan (沃川陸氏) The apical ancestor of the Okchŏn-Ryuk clan is said to have been $\mathrm{Lu} \mathrm{Pu}$ (陸普), a Tang man who arrived in Silla in 927 and subsequently settled there. The founder of the Okchŏn-Ryuk clan was Ryuk Indan (陸仁端), a Koryŏ man who lived during the reign of King Ch'ungyŏl (忠烈王, r. 1274-1308).

\subsection{Foreign Family Names in the Koryŏ Period}

\subsubsection{Family names from China}

Several dozen clans originated from China during the Koryŏ dynasty: the Ch'ungju-Ch'i clan (忠州池氏), Hamjong-Ŏ clan (咸從魚氏), Hamp'yŏng-Mo clan (咸平牟氏), Hyŭnp'ung-Kwa clan (玄風郭氏), Kanghwa-Wi clan (江華韋 氏), Kŏcang-Sin clan (居昌懭氏), Kŏcang-Yu clan (居昌劉氏), Kyŏnju-Sŏp clan, (慶州葉氏), Kwangchŏn-Tong clan (廣川董氏), Nŭngsŏng-Ku clan (綾城具氏), Milyang Tang clan (密陽唐氏), Posŏng- Sŏng clan (寶城宣氏), Sangsan-Lee clan (商山李氏), Sinan-Chu clan (新安朱氏), Sinchang-P'yo clan (新昌表氏), Suan-Kye (遂安桂氏), T'aean Lee clan (泰安李氏), Tanyang-U clan (丹陽禹氏), TamYang-Kuk clan (潭陽鞠氏), Talsŏng-Ha clan (達城夏氏), Talsŏng-Pin clan (達城賓氏), Turŭng Tu clan (杜陵杜氏), Yangsan-chin clan (梁山陳氏), Yŏhŭng-Min clan (驪興閔氏), Yŏnan-Myŏng clan (延安明氏), Yŏngsan-Sin clan (靈山辛氏), Yǒyang-Chin clan (聏陽陳氏), etc.

While the putative apical ancestors of these clans are said to be from the Song (宋朝, 960-1279), Yuan (元朝, 1279-1368), and Ming dynasties (明朝, 1368-1644), a good number of them were from the Song. Most of these putative apical ancestors were scholars invited to Korea, Chinese envoys, or refugees who fled the incursions of northern peoples. As there is considerable detail about the relationships between these putative apical ancestors and their descendants, chances are good that these ancestors, unlike those of the pre-Koryŏ foreign clans, did in fact originate in China.

The following examples give a better idea of the formation of these clans in Korea.

Kŏcang-Sin clan (居昌愼氏) Shen Xiu (懭修) is said to have been the apical ancestor of the Kŏcang-Sin clan. Shen was a Song dynasty resident of Kaifeng (開封) who came to Koryŏ during the reign of King Munjong (文宗, r. 1046-1083). Because he was a learned man and adept in medical practice, Shen was appointed to an official post. Shen Xiu is recorded in the History of 
Koryŏ.

Kŏcang-Yu clan (居昌劉氏) The apical ancestor of the Kŏcang-Yu clan is said to have been a Song scholar dispatched to Koryŏ during the reign of King Munjong.

Sinan-Chu clan (新安朱氏) The Sinan-Chu are said to have descended from Zhu Qian (朱潛), a great-grandson of Zhu Xi (朱喜). Zhu Qian settled in Korea to flee the Mongol Invasions of 1224 . He subsequently became the putative apical ancestor of the Sinan-Chu.

Nŭngsŏng-Ku clan (綾城具氏) The apical ancestor of the Nŭngsŏng-Ku clan is said to have been Ju Cunyu (具存裕), who, along with Zhu Qian (朱潛), fled the Mongol Invasions of 1224 and settled in Koryŏ.

Kwangchŏn-Tong clan (廣川董氏) The apical ancestor of the KwangchŏnTong clan is said to have been Dong Chengxuan (董承宣), the forty-third descendant of the Western Han scholar Dong Zhongshu (董仲舒). Dong came to Koryŏ as an envoy from the Ming and settled there. The ancestral seat of the Kwangchŏn-Tong clan is China’s Guangchuan (廣川), Dong Zhongshu's birthplace.

\subsubsection{Family names from those who followed Yuan princesses to Koryŏ}

During the Yuan dynasty, princesses were often married off to Koryŏ royalty. Between the reigns of King Ch'ungyŏl (忠烈王, r. 1236-1308) and King Kongmin (恭㟲王, r. 1351-1374), approximately eighteen clan ancestors were said to have accompanied the princesses and settled in Koryŏ. The following clans have such origins: the Anŭm-Sŏmun clan (安陰西門氏), Ch’ŏngju-Yang clan (清州楊氏), Chuksan-Ǔm clan (竹山陰氏), Hanam-Chŏng clan (河南程氏), Wŏnju-Pyŏn clan (原州邊氏), Hoesan-Kam clan (檜山甘氏), Kaesŏng-No clan (開城路氏), Kaesŏng-Pang clan (開城龐氏), Kŏje-Pan clan (巨 濟潘氏)，Kokpu-Kong clan (曲阜孔氏)，Kosan-Yan clan (谷山延氏), Kŭmsŏng-Pŏm clan (錦城范氏), Munkŏng-Chŏn clan (聞慶錢氏), P'ungch'ŏn-Im clan (豊川任氏), Yŏnan-In clan (延安印氏), Sunch'ŏn-To clan (順天陶氏), Tǒksu-Chang clan (德水張氏), and Yonggang-P'aeng clan (龍岡彭 氏).

\subsubsection{Family names from other ethnic groups}

There are instances of Uighurs, Vietnamese, and Jurchens settling in Korea during the Koryŏ dynasty, but I will avoid going into too much detail here. 
Yŏnan-In clan (延安印氏), Tŏksu-Chang clan (德水張氏) Those who accompanied the Yuan princesses included non-Han Chinese people as well. The putative apical ancestor of the Yŏnan-In was Inhu (印候), a Mongol. He accompanied a Yuan princess and arrived in Koryŏ in 1257. He subsequently received a surname from the King of Koryŏ. The putative apical ancestor of the Tŏksu-Chang was an Arab who also followed a Yuan princess to Koryŏ. He received the name of Chang Sunyong (張舜龍) from the Koryŏ king, and his arrival in Koryŏ is recorded in the History of Koryŏ.

Kyŏnju-Sŏl clan (慶州偰氏) Sŏl Son (奜遜), the putative apical ancestor of the Kyŏnju-Sŏl clan, was a high-ranking Uighur official of the Yuan dynasty who settled in Koryŏ during the Red Turban Rebellion（紅巾之亂，13511366). As Sŏl Son had already interacted with King Kongmin (恭憵王) as an official of the Yuan, he was appointed to an official post in Koryŏ and bestowed the family name of Sŏl. Sŏl is said to be a reference to the Selenga River in his hometown.

Hwasan-Lee clan (花山李氏) Lee Yongsang (李龍祥), the putative apical ancestor of the Hwasan-Lee, is said to have been a royal of the later Ly dynasty (李朝) in Annam (安南). When the Ly dynasty fell to the Tran (陳朝), Lee in 1226 emigrated to Koryŏ by way of Song.

Chŏnhae-Lee clan (靑海李氏) The putative apical ancestor of the Chŏnhae-Lee was a Jurchen by the name of Li Chi'lan (李之蘭), who settled in Koryŏ in 1351 and was bestowed Chŏnhae as his ancestral seat. Lee had pacified Japanese pirates and aided in the establishment of the Chosorn dynasty (朝鮮, 1392-1897), which led to his being recognized as a meritorious subject in Chosŏn.

In the historical records of Koryŏ and Chosŏn, many Jurchens and Manchus are said to have immigrated to Korea and established family names. However, in current Korean genealogies, Chŏnhae-Lee is the only clan that claims Jurchen ancestry. This is in great contrast to the many clans that claim to have descended from China. Presumably, the geographical proximity of the Jurchens and Manchus to Korea led many of them to immigrate. Yet most of their descendants did not record their Jurchen or Manchu ancestries in their genealogies.

\subsection{Foreign Family Names in the Chosŏn Dynasty}

\subsubsection{Chinese family names in the first half of the Chosonn dynasty}

Comparatively few clan names came from China during the early half of 
the Chosŏn dynasty. They include those of the Kyŏnju-Ping clan (慶州水氏) and the Chinju-Nang clan (晋州浪氏). It seems that not many people migrated from China to Chosonn during this period. The putative apical ancestor of the Kyŏnju-Ping clan, Bing Rujing (水如鏡), is said to have been a Ming envoy who came and settled in Chosŏn in 1467.

\subsubsection{Chinese family names that entered Chosŏn during Hideyoshi's invasions and at the fall of the Ming dynasty}

Many Chinese came and settled in Chosŏn during Hideyoshi's invasions of Korea (壬辰倭亂, 1592-1598), and also at the fall of the Ming dynasty (1644). The surnames that resulted from these movements include the Chŏlgang-Chang clan (浙江張氏), Chŏlgang-P'yŏn clan (浙江片氏), Chŏlgang-Si clan (浙江施氏), Chŏlgang-Sŏ clan (浙江徐氏), Chŏnju-Ho clan (全州扈氏)，Haeju-Sŏk clan (海州石氏)，Hapch’ŏn-Ma clan (陝川麻氏), Kangŭm-Tan clan (江陰段氏), Kanghwa-Man clan (江華萬氏), Kanghwa-Sa clan (江華史氏), Kwangdong-Chin clan (廣東陳氏), P'arŭng-Ch'o clan (巴陵楚氏), P'arŭng-Ho clan (巴陵胡氏), Soju-Ka clan (蘇州賈氏), Yŏngyang-Ch’ŏn clan (穎陽千氏), etc. There are two main reasons why these people came and settled in Chosŏn. Some members of the Ming army that aided Chosŏn during Hideyoshi's invasions decided to remain in Korea, while others first went back to China, then returned to Chosonn upon the fall of the Ming dynasty. Many ordinary Chinese also immigrated to Chosŏn after the fall of the Ming. Many of the ancestral seats of these clans are located in China. The following are a few examples.

Chŏlgang-Si clan (浙江施氏) The putative apical ancestor of the Chŏlgang-Si clan was a Ming soldier by the name of Shi Wenyong. (施文用). He came as a member of the Ming army to repel Hideyoshi's invasion and decided to remain in Chosŏn to recover from injuries sustained in battle.

Kwangdong-Chin clan (廣東陳氏) The putative apical ancestor of the Kwangdong-Chin clan was Chen Lin (陳璘), a Ming general who fought to repel Hideyoshi's invasions of Korea. When the Ming dynasty fell to the Qing in 1644, Chen Lin's grandson, Chen Yongsu (陳泳素) came and settled in Chosŏn through his grandfather's connections.

Soju-Ka clan (蘇州賈氏) Jia Weiyue (賈維錀), a Ming dynasty man from Suzhou, is said to have been the apical ancestor of the Soju-Ka clan. Jia had come to Korea as a member of the Ming army to repel Hideyoshi's invasions of Korea and died in battle. When the Ming dynasty fell to the Qing in 1644, his grandson Jia Chen (賈樔) is said to have fled to Chosŏn. 
P'arŭng-Cho clan (巴陵楚氏) Chu Haichang, (楚海昌), the putative apical ancestor of the P'arŭng-Cho, was a Ming dynasty official who fled to Chosŏn upon the fall of the Ming dynasty in 1664.

\subsubsection{Family names that arrived in Korea with the return of Chosŏn prince hostages to the Qing}

After the second Manchu invasion of 1636 (丙子胡亂), several Chosŏn princes were taken as hostages to Shenyang (瀋陽). When one of the princes, Ponglim Taegun (鳳林大君), returned to Chosŏn, he brought with him nine Chinese men guilty of resisting the Qing and plotting a Ming restoration. Owing to their crimes, those men too were held captive in Shenyang. The nine who accompanied Ponglim Taegun back to Chosŏn were Huang Gong (黄功), Wang Wenxiang (王文祥), Wang Yiwen (王以文), Wang Meicheng (王 美承), Feng Sanshi (馮三仕), Pei Sansheng (韭三生), Zheng Xianjia (鄭先甲), Yang Fuji (楊福吉), and Liu Xishan (柳溪山). Of the nine clans that they founded, only the Imgu-P'ung clan (臨朐馮氏), Nangya-Ch'ŏn clan (瑯㑚鄭氏), and Chenam-Wang clan (濟南王氏) remain in Korea today. The ancestral seats of all three clans are their founders' hometowns in China.

\subsubsection{Japanese family names}

Korea and Japan have a long history of intermigration. It is well known that ancient people living on the Korean peninsula migrated to Japan, and numerous Japanese migrated to Korea as well. It is thought that in ancient times the Japanese often traveled to the southern part of the Korean peninsula, and that some are likely to have settled there. From medieval to early modern times, the southern part of the peninsula had three open trade zones for the Japanese, and many Japanese resided in those areas. In the History of Koryo, records for the years 999, 1012, and 1039 mention that several Japanese chose to join Koryŏ. In the Annals of the Chosŏn Dynasty (朝鮮王朝 實錄), similar records for 1425,1426 , and 1435 state that several Japanese chose to join Chosŏn and were bestowed family names by the king. However, most family names of Japanese origin in Korea have been lost, with only two remaining today:

Urok-Kim clan (友鹿金氏) The putative apical ancestor of the Urok-Kim clan was a Japanese man named Sayaka (沙也可), who was initially a member of Hideyoshi's invasions of Korea but chose to surrender to Chosŏn. He distinguished himself in military service fighting the Manchus and was subsequently appointed to a high-ranking position. The Chosŏn king subsequently bestowed on him a Korean-style family name. 
Hambak-Kim clan (咸朴金氏) The putative apical ancestor of the Hambak-Kim clan is also a Japanese soldier who surrendered to Chosŏn during Hideyoshi's invasions. He too received a Korean-style family name from the king and was appointed as an official.

The origins of other foreign family names are unclear. What we do know is that most of such names trace their roots to China.

\subsection{A Comprehensive Study of Premodern Foreign Family Names in Korea}

So far I have examined foreign family names in premodern Korea. On the basis of this examination, we can take the origins of Chosŏn-period foreign family names as basically historical. The origins of several Koryŏperiod foreign family names can also be demonstrated as factual. However, the veracity of the origins of many foreign family names cannot be substantiated with any historical documentation other than the clan's own genealogical records. Moreover, clans of foreign origin founded before the Koryo period do not possess genealogical records that clearly detail the relationship between the putative apical ancestor and the founder. Hence, it is impossible to confirm whether they accurately reflect the putative apical ancestor's migration to Korea.

In this section I will analyze the family names and genealogical records of premodern Korea. I will also examine how people migrated to Korea in a historical context. Through these studies I hope to better understand and explain the existence of so many foreign family names in Korea.

\subsubsection{The formation and characteristics of premodern Korean family names}

Korean family names began with the introduction of Chinese culture and Chinese characters, in particular. If we look at Silla steles from the sixth century, for example, people are recorded without family names, but only with their given names and tribal or village affiliations. This demonstrates that ancient Korean society referred to people by given names and not surnames. As ancient Koreans came into contact with China, they began to adopt Chinese-style family names. Royalty and the central aristocracy of Koguryo and Paekche adopted family names between the fourth and fifth centuries, while in Silla, family names began to be used around the sixth century.

Viewing the formation and dissemination of family names in Korea by period, we can say that the use of Chinese-style family names among royalty and the central aristocracy occurred in the latter half of the Three Kingdoms 
and Unified Silla periods. During early Koryŏ times, the use of family names spread among the rest of society's ruling elite, and a system of clans and ancestral seats was established. In 1055 a law allowing only those with family names to take the state examinations (科擧試驗) was promulgated, and this greatly accelerated the use of family names among the elite. Ordinary citizens (良民) began adopting family names throughout the first half of the Koryŏ period. From the tenth century, some of the lowest class of people (賤 民層) could obtain family names after being freed from their low status. In the fifteenth and sixteenth centuries, the lowest caste of people without surnames comprised half of the total population of Chosonn. ${ }^{3}$ Most lowborn people began to acquire family names in the late sixteenth century. With the Kabo reforms (甲午更張) of 1894, family names were completely disseminated in Korea, and the Law of Census Registration (民籍法) of 1909 legally allowed anyone to obtain a family name and ancestral seat.

Now we will take a closer look at how, from the late Three Kingdoms to the Unified Silla period, many family names began to form according to surname usage among royalty, the central aristocracy, envoys sent to China, and Koreans studying in China.

The royal family of Koguryŏ was the Ko clan (高氏), Paekche royalty belonged to the Puyŏ (扶餘氏) or Yŏ (餘氏) clans, Silla's royals were members of the Pak (朴氏), Sok (昔氏), and Kim (金氏) clans, and the royal family of Kaya (伽㑡, 42-562) was the Kim clan (金氏). Most of these royal clans have putative apical ancestors associated with myths. The Koguryŏ royal clan's putative apical ancestor, Chumong (朱蒙), is said to have been born from an egg produced from the union between the son of the heavenly god (天帝) and the daughter of the river god. The Ko family name is said to come from the name Koguryŏ or from the fact that Chumong was born from an egg lit from on high by sunlight. The Paekche royal clan's putative apical ancestor, Onjo (溫宱), is said to be a son of Chumong. He is said to have taken the name Puyo from the state of Puyŏ, the parent kingdom that gave birth to both Paekche and Koguryŏ. The Silla royal clan's putative apical ancestor, Hyokkose (赫居世), was given the surname Pak because it was said that he was born from an egg that looked like a gourd, which is called pak in Korean. Both Alji (䦥智), another putative apical ancestor of Silla, and Suro (首露), the ancestor of Kaya, obtained the surname Kim because they were said to have been born from golden eggs. T'alhae (脱解), the third putative apical ancestor of Silla, was also born from an egg, then having been cast out

3 Yi Su-gŏn 2003, pp. 333-338. "Korean Family Names," in Encyclopedia of Korean Culture (Seongnam: Academy of Korean Studies, 1991), vol. 12, pp. 467-477. 
to sea and discovered by a magpie. The character for his surname, Sok (昔), was said to have been derived from the character for magpie (鹊).

Owing to the influence of the Chinese system of surnames, royal families began to form new family names by connecting them to the founding myths of human births from eggs. Through this process, Silla and Kaya created the Kim and Pak surnames, which are very rare, if not entirely unused, in China. On Cheju island (濟州島), south of the peninsula, there existed the independent kingdom of T'amna (耽羅), whose three founders sprouted from the ground with the surnames Ko (高), Ryang (良), and Pu (夫).

After royalty adopted Chinese-style family names, they began creating new surnames by bestowing family names upon members of the aristocracy. In Silla, the elites of the six tribes of Yangbu (梁部), Saryangbu (沙梁部), Chomryangbu (漸梁部), Ponpibu (本彼部), Hanjibu (漢祗部), and Sub'bibu (習 比部) were bestowed the surnames of Lee (李), Ch'oe (崔), Son (孫), Chong (鄭), Pae (裵), and Sol (薛). Silla is said to have used other family names, such as Chang (張) and Yo (姚), as well. Most Korean family names originated in Unified Silla. The Silla and Kaya royal clans Kim and Pak, together with the Silla aristocratic clans of Lee, Ch'oe, and Chong, later came to form the five main clans of Korea.

In Koguryŏ the elite used such family names as Ǔl (乙), Ye (禮), Song (松), Mok (穆), U (于), Chu (周), Ma (馬), Son (孫), Chang (倉), Tong (董), Ye (苗), Yŏn (淵), Myŏnglim (明臨), and Úlji (乙支), which coexisted with legendary surnames such as Wi (位), Wu (羽), Nak (洛), Puchŏn (負鼎), Taesil (大室). In Paekche the eight main families were the Chin (眞), Hae (解), $\mathrm{Sa}$ (沙), Yŏn (燕), Paek (白), Kuk (國), Mok (木), and Hyŏb (劦), while other elites used such surnames as Wang (王), Chang (張), Sumi (首彌), Koi (古爾), Sama (司馬), and Hŭkchi (黑齒). After Koguryŏ and Paekche fell to Silla and Tang in the seventh century, their royal family names, as well as many aristocratic surnames, ceased to be used. Hence, very few clans are considered descendants of Koguryŏ or Paekche.

Many new family names were formed when Wang Gŏn (王建) founded the Koryo dynasty in 918 and bestowed surnames upon local gentry who had extensively contributed to the establishment of the dynasty (開國功臣). For example, Hongsul (弘述) was given the surname of Hong (洪), while Paeoksam (白玉衫), Samnŭngsan (三能山), and Poksakwi (卜沙貴) received the surnames of Pae (裴), Sin (申), and Pok (卜), respectively. Until that time, these people lacked surnames and were referred to only by their given names.

The following family names were received during Koryŏ period, and their clans became powerful in government (starred clans are those that originated with a founder from China): the Andong-Chang clan (安東張氏)*, Andong-Kŭn clan (安東權氏), Changhŭng-Im clan (長興任氏)*, Ch'ogye-Chŏng 
clan (草溪鄭氏), Ch'ilwŏn-Yun clan (漆原尹氏), Chinju-Kang clan (晋州姜氏), Chinju-Yu clan (晋州柳氏), Chŏndo-Kim clan (清道金氏), Chŏnju-Ch'oe clan (海州崔氏), Ch'ŏnju-Han clan (清州韓氏)*, Ch'ŏngju-Kim clan (清州金氏), Ch'ŏnju-Kyŏng clan (清州慶氏)*, Ch'ŏngju-Kwak clan (清州郭氏), ChuksanPak clan (竹山朴氏), Habch'ŏn-Lee clan (陝川李氏), Haeju-Choe clan (海州崔 氏), Haengju-Ki clan (幸州奇氏)*, Haep’yŏng-Yun clan (海平尹氏), Hansan Lee clan (韓山李氏), Hoengsŏng-Cho clan (横城趙氏), Ich'ŏn-So clan (利川徐氏)*, Iksan-Lee clan (益山李氏), Ilsŏn-Kim clan (一善金氏), Inch'ŏn Lee clan (仁川 李氏), Kohŭng-Yu clan (高興柳氏)，Kyŏngju-Choe clan (慶州崔氏), Kyŏngju-Kim clan (慶州金氏), Kyŏngju-Lee clan (慶州李氏), Kwangsan-Kim clan (光山金氏), Munhwa-Yu clan (文化柳氏), Musong-Yu clan (茂松廣氏)*, Namp'yŏng-Mun clan (南平文氏), Namyang-Hong clan (南陽洪氏)*, Ŏnyang-Kim clan (彦陽 金氏), P'ap'yŏng-Yŭn clan (坡平尹氏), P'yŏnggangCh'ae clan (平康蔡氏), P'yŏnsan-Yu clan (平山英氏), P'yŏngyang-Cho clan (平 壤趙氏), Puan-Kim clan (扶安金氏), Pugye-Hong (缶溪洪氏), Sinchŏn-Kang clan (新川康氏)*, Sŏnju-Lee clan (星州李氏), Sowŏn-Yŏm clan (瑞原廉氏), Sunchang-Sol clan (淳昌薛氏), Sunŭng An clan (順興安氏), Tanyang-U clan (丹 陽禹氏)*, Tŏksu-Lee clan (德水李氏), Tongbok-O clan (同福吳氏), Tongju-Choe clan (東州崔氏), Ubong-Choe clan (牛峰崔氏), Wŏnju-Wŏn clan (原州元氏), Yangch'ŏn-Ho clan (陽川許氏), Yangsŏng-Lee clan (陽城李氏)*, Yŏhŭng-Min clan (驪興閺氏)*, Yŏnchŏn Hwangbo clan (永川皇甫氏)*, Yŏyang-Song clan (礪良宋氏), etc. Among these clans, some originated in the Silla period, while others were newly formed in the Koryŏ period. Most family names in contemporary Korea can be found in this list. One observation supported by this list is that quite a few Koryŏ elite clans claim to originate from China. Family names of Chinese origin were scarce during the Three Kingdoms and Unified Silla periods, but they suddenly increased in the Koryŏ period.

Analyzing the formation of Korean family names from the Three Kingdoms to the Koryo period, we can arrive at the following conclusions. Though ancient Korean society possessed only given names and no surnames, relations with China and cultural influence from China prompted the adoption of Chinese-style family names (漢姓). During the process of adoption, the kings of Koguryŏ, Silla, and Kaya created new family names by connecting the names to their state foundation myths. Paekche rulers took the name Puyŏ (扶餘), the name of their originators, as the royal clan name (王姓). Likewise, Ko (高) and Kim (金), the royal family names of Koguryŏ, Silla, and Kaya, despite having also been used in China, became completely different surnames in Korea. Pak, another royal Silla clan, was a family name that did not exist in China, and Paekche also formed family names unique to their state. The Ko (高), Pu (夫), and Ryang (良) clans of T'amna on Cheju Island were also given an indigenous origin by way of a foundation myth. Thus, we 
can see that in this way ancient Korean kingdoms did not merely adopt Chinese style family names, but rather adapted the family names to their foundation myths. Fantastic myths and tales concerning founders were not restricted to royalty, but can be found among aristocratic clans as well. The putative apical ancestor of the Namp'yŏn-Mun clan (南平文氏) was a child born in a stone crate in the Silla period. It is said that because of his intelligence, the king of Silla bestowed upon him the name Mun (文). The putative apical ancestor of the Haŭm-Pong clan (河陰奉氏) was also found in a stone crate, by a lake during the Koryŏ period. It is said that the old woman who discovered the child offered him to the king, whereupon the king created the name Pong (奉) for the child. The putative apical ancestor of the P'apyŏng-Yun (坡平尹氏) was discovered in a jade box in a lake during the Koryo dynasty. The old woman who discovered the child gave it her own family name of Yun.

Elites also independently adopted Chinese-style family names in unique ways. In the case of Koguryŏ and Paekche elites, some adopted Chinese surnames outright, while others took names of a more indigenous character. For example, the family name of Hae (解) is taken from the Korean word for sun as a reference to the foundational myths of Koguryŏ and Paekche. Other surnames, such as Ǔlji (乙支) and Hŭkchi (黑齒), were perhaps Koguryŏ or Paekche given names or tribal names transformed into family names. The founder (太祖) of Koryŏ, Wang Gŏn (王建), bestowed family names on meritorious subjects who helped found the dynasty. The family names he gave, such as Hong (洪), Pae (裴), and Pok (卜), corresponded to the first letters of the subjects' given names. Hence, Koreans did not simply take on Chinesestyle family names, but rather created new names by relating them to given names, tribal names, and myths. Similar phenomena can be seen in the adoption of Chinese-style family names among the Mongols, Manchus, and other northern nomadic peoples. In the case of Silla, however, such independent adaptation cannot be found. Instead, the Silla elites of the six tribes (部) adopted their family names-Lee (李), Ch'oe (崔), Son (孫), Chŏn (鄭), Pae (裴), and Sol (薛) — from powerful Tang dynasty clans.

In the early Koryŏ period, the use of family names spread to everyone in the aristocratic class, and during the first half of the Koryŏ dynasty it eventually extended to regular citizens. In this process of adoption, many took on Chinese-style family names and connected their putative apical ancestor to China, despite no real historical connection. Though during the Three Kingdoms and Unified Silla periods few related their putative apical ancestor to China, this practice increased during the Koryŏ period. Chinese culture and institutions were imported in great quantities throughout the Three Kingdoms and Unified Silla periods, and as Chinese characters, Confucianism, and 
Chinese systems became well established, Korean upper-class people increasingly came to esteem and admire China. This mindset vis-à-vis China seems to account for the sudden increase in family names of Chinese origin. As I have shown earlier, some clans had an actual apical ancestor from China. Many other clans, however, connected their putative apical ancestor to China without reference to historical fact, simply because their family names were identical to those used in China. The respect for Chinese culture in premodern Korea no doubt encouraged this practice.

As mentioned earlier in this discussion, some clans claim that their putative apical ancestors were descendants of Kija, or were connected to the Han dynasty, or came over to Korea from China during the Three Kingdoms or Unified Silla period. Most of these clans do not possess records linking their putative apical ancestors to their actual founders, and historical clan founders were by and large people of the Koryŏ dynasty. This shows that in the Koryŏ period, when forming family names by adopting Chinese-style family names, people began to link their putative apical ancestor to China. This phenomenon continued during the Chosonn dynasty as well, because while the use of family names was well established among Koryŏ elites, regular citizens and people of the lower class continued to adopt surnames up until the end of the Chosŏn dynasty. Moreover, although genealogical records were first kept in Koryŏ, they became widespread only in the Chosŏn dynasty. It seems that in the process of creating and disseminating genealogical records, many clans began to formulate new stories of origins connecting them to their putative apical ancestors. Even among ancient Korean ruling families that created new family names from state formation myths, some clans show signs of connecting their putative apical ancestors to China. In the History of the Three Kingdoms (三國史記), an entry during the reign of King Kwanggaet'o (廣開土 王, r. 391-412) states that the Koguryo ruling family adopted the surname Ko (高) because they believed themselves to be descendants of Zhuanxu Gaoyang (顓項高陽氏), grandson of the mythical Huangdi (黄帝). ${ }^{4}$ In the biography of Kim Yusin (金序信), a stone monument to him is said to have recorded Kim as the descendant of Shaohao Jintian (少吴金天氏), the son of Huangdi (黄帝), ${ }^{5}$ despite the fact that Kim was known to be a Silla general with Kaya royal blood. Silla royal clans in general seem to have identified themselves as the descendants of Shaohao Jintian. The Ko clan of Koguryŏ as well was likely identified as descendants of heroic figures of Chinese myth, and similarly for the Kim royal clans of Kaya and Silla.

4 Kim Pu-sik 金富軾, 三國史記 (History of the Three Kingdoms), trans. by Kim Sa-yŏp 金思燁 (Tokyo: Akashi Shoten, 1997), p. 373.

5 Kim Chŏn-ho 2003, pp.99-101. 
Despite numerous family names of foreign origin in contemporary Korean society, the clans with the largest populations in Korea today tend to be indigenous. In the 2000 census, the top ten most common family names were Kim (金), Lee (李), Pak (朴), Ch’oe (崔), Chŏng (鄭), Kang (姜), Cho (趙), Yun (尹), Chang (張), and Im (林). The top ten most populous clans were the Kimhae-Kim clan (金海金氏), Milyang-Pak clan (密陽朴氏), Chŏnju-Lee clan (全州李氏), Kyŏngju-Kim clan (慶州金氏), Kyŏngju-Lee clan (慶州李氏), Kyŏngju-Ch’oe clan (慶州崔氏), Chinju-Kang clan (晋州姜氏), Kwangsan-Kim clan (光山金氏), P'apŏng-Yun clan (坡平尹氏), and Ch'ŏngju-Han clan (清州韓 氏). ${ }^{6}$ Of these surnames and clans, those that have putative apical ancestors from China are the Cho, Chang, Im, and Ch'óngju-Han, and they are far outnumbered by clans with indigenous origins. In fact, foreign family names founded by those who immigrated between the late Koryŏ and Chosŏn periods are quite rare, and their numbers few. Moreover, while populous surnames of foreign origin such as Cho, Chang, Im, and the Ch'ŏngju-Han claim ancestry from China, verifying this is nearly impossible. Thus, while family names of foreign origin are numerous and make up almost half of all family names in Korea, their populations are comparatively small.

\subsubsection{Historical context of premodern family names of foreign origin in Korea}

This section will analyze the use of foreign family names from the perspective of historical population migrations to the Korean peninsula in premodern times.

The first migration to the Korean peninsula in the historical records is that of Kija's easterly migration (箕子東來說). However, the historicity of Kija is unclear, as is that of the ancient state called Kija Chosŏn (箕子朝鮮). An archaeological find has shown that people who used the surname of Ji (箕) lived in northern China during the Shang and Zhou dynasties, and so there is a chance that these people migrated to Manchuria or the northern part of the Korean peninsula during the transition from Shang to Zhou. While there are several Korean clans that claim to be descended from Kija, the founders of these clans were all Koryŏ-period figures whose exact relations with their putative apical ancestor are not recorded. Hence, there is a chance that these claims were fabricated in later generations. There is also a chance that these clans are somehow related to the myth of the last king of Kija Chosŏn, who fled from the Yan (燕國) general Wiman (衛滿) to the southern half of the Korean peninsula and ruled over the Han (韓) people. And since Wiman is

6 "The Historical Development of Korean Family Names," in Doopedia (http:// www.doopedia.co.kr/). 
known to have actually existed, the last king of Chosŏn, Ki Jun (奇準), may have existed as well. It is therefore possible that the clans claiming to have descended from Kija had ancestors among Ki Jun's group, which established another polity in the southern half of the peninsula.

According to Chinese records, during the Qin dynasty's unification of China and again during the transition from Qin to Han, many people living in China's northern regions fled by the tens of thousands to Manchuria and the Korean peninsula to avoid turmoil. This was probably the beginning of population migration from China to Korea. It was during this movement that Wiman Chosŏn (194-108 BCE), a state dominated by Chinese immigrants, was established, followed by the establishment of the four Han commanderies (漢四郡) in $107 / 8$ BCE. It is easy to imagine that many people moved from China to Korea during the rule of the commanderies. Still, from an examination of the origins of Korean family names, we see that there are surnames relating to Kija, but none that relate directly to Wiman, and very few that are connected to the Han commanderies.

The next recorded period of mass migration out of China was during the Chinese Three Kingdoms, the Western and Eastern Jin dynasties, and the Northern and Southern Dynasties periods. For example, the History of the Three Kingdoms (三國史記) states that in 217, Xiayao (夏瑤), of Pingzhou (平 州), brought with him over a thousand households and submitted to Koguryo. ${ }^{7}$ The owner of Anak (安岳) Tomb No. 3 was Tong Su (董壽), an official from Early Yan (前燕) who emigrated to Koguryŏ in 336. We can see, from the many tombs and grave goods left by people, that even after the fall of the Han commanderies, many Chinese people continued to live on old commandery lands. However, almost no Korean family names from this period have Chinese putative apical ancestors.

It can be said that from the end of the Chinese Warring States period to the Northern and Southern Dynasties, many Chinese moved to Manchuria and the Korean peninsula, blended among the indigenous people, and over time forgot about their Chinese origins. The Chinese came to the Korean peninsula when Koreans were not using family names. The arrival of Chinese migrants must have stimulated the adoption of Chinese-style family names among Koreans at the time.

Many Chinese also likely migrated as Chinese Buddhism, Confucianism, Daoism, laws, and governing systems were introduced to Korea during the Chinese Western and Eastern Jin, Northern and Southern Dynasties, and Sui and Tang periods. Among Korean foreign family names, there are approxi-

7 Kim Pu-sik 金富軾, 三國史記 (History of the Three Kingdoms), trans. by Kim Sa-yŏp 金思燁 (Tokyo: Akashi Shoten, 1997), p. 338. 
mately ten clans whose putative apical ancestors are said to have been Chinese scholars who arrived in Koguryŏ or Silla as members of the Eight Scholars Group. While such claims may seem fabricated, it was nonetheless true that many scholars came to the Korean peninsula during this time period.

Large-scale migratory movements of people from China to the Korean peninsula almost ceased in the Unified Silla period. However, many people did come to Korea during the Koryo dynasty to escape the chaos of the Chinese Five Dynasties and Ten Kingdoms period and the incursion of northern nomadic tribes in the Song. Several clans of foreign origin in Korea have putative apical ancestors who are said to have fled to Koryŏ to avoid political turmoil and nomadic raids.

In the late Koryo period, many people from China settled in Korea when five Koryŏ kings wed Yuan princesses. The History of Koryo records that during the transition period between Yuan and Ming, many northern Chinese fled to the peninsula. Similar records can be found among clans of foreign origin in Korea.

In addition, many Ming dynasty soldiers who came to aid Chosŏn during Hideyoshi's invasions settled in Korea. Afterwards, during the transition from Ming to Qing, many scholars who refused to be ruled by the Qing, as well as some descendants of Ming soldiers who had been in Korea to combat Hideyoshi's invasions, came to settle in Ming-friendly Chosŏn. Quite a few clans of foreign origin have putative apical ancestors that arrived in Korea in this time period.

As we can see, migratory movements from China to Korea continued over long periods of time, and many of those movements were reflected in the formation of foreign family names in Korea.

As the geography of the Korean peninsula suggests, it is not farfetched to say that many Manchus, Khitans, and Japanese as well must have settled in Korea. However, among Korean clans of foreign origin, those that originated from China form the majority, and only very few claim to have descended from Japanese or Manchus. This is because Koreans adopted Chinese-style family names owing to their high regard for Chinese culture. The paucity of non-Chinese foreign family names may be due to the fact that Koreans tended to look down upon the cultures of the Manchus, Khitans, and Japanese.

\section{Foreign Family Names in Ancient Japan}

\subsection{Ancient Japanese Immigrants in Historical Context}

Unlike foreign family names in premodern Korea, the system in ancient Japan was relatively complicated. Therefore, to understand the foreign family 
names of ancient Japan, we must first examine the history of immigration to Japan.

Immigration to the Japanese archipelago occurred most frequently between the Yayoi (弥生時代) to Asuka (飛鳥時代) periods, from the third (or fifth) century BCE to the seventh century. The physical anthropologist Haniwara Kazurô once made headlines by arguing that over a period of a thousand years, approximately one million people immigrated to the Japanese archipelago. ${ }^{8}$ Foreign immigration into Japan can be divided into the following four phases:

\subsubsection{From the third century BCE to the third century CE}

During the third (or fifth) century BCE to the third century CE, Japan experienced a large cultural change in the Yayoi period. Rice farming, which came to Japan by way of China and the Korean peninsula, and the dissemination of bronze and iron production, weaving techniques, and iron farming implements allowed the hunter-gatherers of the Jōmon period (縄文時代) to transition into an agricultural society.

The Japanese archipelago during the Yayoi period is thought to have experienced a large shift in ethnic makeup as well. Anthropological theories based on physical traits of Japanese skulls and mitochondrial DNA assert that new groups of people from China and Korea settled in the Japanese archipelago, and that the indigenous Jomon people and foreign Yayoi people combined to create the Japanese people. Japan's Yayoi period coincided with China's Warring States period, Qin dynasty, Han dynasty, and Three Kingdoms period. Historical records show that many Chinese fled the chaos of the Chinese mainland to the Korean peninsula. With the formation of the four Han commanderies in the first century BCE, many Chinese settled in Korea. It is not difficult to imagine that a portion of the same movements of Chinese emigrants would have moved to the Japanese archipelago during the Yayoi period.

As is well known in China and Japan, Xu Fu (徐福) set out to the east in search of an elixir for immortality for Qin Shihuang (秦始皇). During the same time period, the Chronicles of Japan (日本書紀) and the Record of Ancient Matters (古事記), two of the oldest Japanese histories, record the myth of the Silla prince Amenohiboko (天日槍) and the Kaya prince Tsunugaarashito (都 怒我阿羅斯等) coming to Japan during the reign of Emperor Suinin (垂仁天皇, allegedly r. 29 BCE-70 CE). Shrines and geographic names relating to

8 Haniwara Kazurô 埴原和郎, “Nihonjin no keisei” 日本人の形成 (The Formation of the Japanese People), in Nihon tsūshi 日本通史, ed. by Asao Naohiro 朝尾 直弘 et al. (Tokyo: Iwanami Shoten, 1993), vol. 1, p. 96. 
Amenohiboko and Tsunugaarashito are spread throughout western Japan. While we cannot take the myths of $\mathrm{Xu} \mathrm{Fu}$, Amenohiboko, and Tsunugaarashito at face value, the stories suggest that people from China and the Korean peninsula were settling in the Japanese archipelago during the Yayoi period.

\subsubsection{From the fourth to fifth centuries}

During this time, the kingdoms of Koguryŏ, Paekche, Silla, and Kaya were established in the Korean peninsula. With the southern campaigns of Koguryŏ on the way, it is possible that many Silla, Paekche, and Kaya people fled to Japan. And in fact, the settlement of the Hata clan (秦氏) of Silla and the Aya clan (漢氏) of Kaya and Paekche is recorded in Japanese histories.

Records of the Hata clan (秦氏) appear in the Chronicles of Japan and the Record of Ancient Matters. There it is said that during the reign of Emperor Ōjin (応神天皇, allegedly r. 270-310), the head of the Hata clan, Yuzukinokimi (弓月君) led a group of people from 120 villages and migrated from southern Korea to Japan. The leaders of this group claimed to be the descendants of the Qin royal family, so they came to be called the Hata (秦) in Japan. They seem to have been Chinese who had resided in the Han commanderies or descendants of Chinese settlers in Korea from an earlier period, not indigenous people of the Korean peninsula. They may have been Chinese residents who were pushed out of Korea with the formation of indigenous kingdoms such as Koguryŏ, Paekche, Silla, and Kaya. While they were originally Chinese, they were likely very Koreanized, having lived on the peninsula for a long period of time. It also seems that many indigenous Koreans were among these groups as well. Thus, the Hata were likely a regional group made up of both Chinese and indigenous Koreans, not exactly a blood-related clan. They first settled in Kyushu and eventually spread throughout western Japan, centered around Kyoto. They were involved in copper and tin mining, sericulture, textile production, and in government they looked after storehouses, worked as scribes, and managed finances. Their woodworking expertise was used in ancient Japanese construction of capital buildings. They were also involved in the establishment and management of important shrines and temples.

The settlement of the Aya clan (漢氏) also appears in the Chronicles of Japan and the Record of Ancient Matters. Like the Hata, the head of the Aya clan, Achinoomi (阿知使主), is said to have led a group of people from seventeen villages in Paekche and to have gone over to Japan during the reign of Emperor Ōjin. This group came to be called the Aya clan (漢氏) in Japan. They arrived in Japan from the southern part of the Korean peninsula, and it is highly possible that they were Chinese residents of the Daifang 
Commandery (帶方郡). The leaders of the Aya claimed to be descendants of the royal family of the Han dynasty. Like the Hata, the Aya, it seems, were Chinese living in the commanderies who were subsequently pushed out with the rise of Koguryŏ, Paekche, Silla, and other indigenous kingdoms. As they had been residing in Korea for a long time, they were likely a regional group with both Chinese and Korean elements mixed in. The pronunciation of Aya (漢) is thought to have derived from Anra (安羅), a polity in the Kaya confederacy in the southern part of the Korean peninsula. The Aya clan mainly settled in the area of Nara and were involved in the iron industry, performed scribal and diplomatic duties, managed storehouses and finances, ran farms belonging to the royal family, and also served as guards in the palace.

Other groups that settled in Japan from Paekche from the fourth to fifth centuries include the Kawachinofumi clan (西文氏). This group mainly settled in the Osaka area, and its putative apical ancestor, Wani (王仁), is believed to have brought Confucian works and Chinese characters to Japan.

\subsubsection{From the late fifth to sixth centuries}

Many skilled workers in the Korean peninsula moved to Japan in the late fifth century. People of the textile industry, along with potters, artists, blacksmiths, tailors, and horsemen settled in the Nara and Osaka regions of western Japan. These people, who claimed to be the descendants of Han dynasty royalty, came mainly from the kingdom of Paekche. They were called Imakinoayato (今來漢人), to distinguish them from the Aya clan that had also come from Paekche, earlier in the fourth to fifth centuries. The ancient Japanese court sent many of the Imakinoayato as diplomats to the Sui and Tang dynasties.

In the sixth century, as Buddhism, Confucianism, and medical knowledge arrived by way of Paekche, many scholars migrated to Japan. Towards the latter half of the sixth century, as Koguryŏ and Japan began having relations, many Koguryŏ monks came over to Japan and constructed temples. A group of Silla immigrants resided in the region of Osaka presently known as Kishi (吉士). These people are said to have been involved in sea trade, pottery production, and diplomatic work.

\subsubsection{The latter half of the seventh century}

Many refugees from Paekche and Koguryŏ fled to Japan when both kingdoms fell to the combined forces of Silla and Tang in the latter half of the seventh century. The Japanese court bestowed the family names of Kudaranokokishi (百濟王) and Komanokokishi (高麗王) to royalty. Several royal family members and aristocrats became officials of the Japanese court, and many were sent to settle the then-frontier areas of eastern Japan. For this 
purpose, Koma district (高麗郡), a Koguryŏ settlement, and Shiragi district (新 羅郡), a Silla settlement, were established in the present-day prefecture of Saitama in 716 and 758 , respectively.

\subsection{Foreign Clans in the Newly Edited Register of Family Names}

Here I will analyze and discuss ancient Japanese foreign family names recorded in the Newly Edited Register of Family Names (新撰姓氏錄) of 815. I would first like to discuss the classification of the 1,182 clans of the capital and its surrounding areas found in the Register. In this document, elites are divided into descendants of the imperial line (皇別), descendants of the gods (神別), and descendants of foreigners (諸藩). Members of the Japanese imperial family after the reign of Emperor Jimmu (神武天皇, allegedly r. 660-585 $\mathrm{BCE})$ are considered to be descendants of the imperial line. There are a total of 335 clans in this category. There are 404 clans classified as descendants of the gods - clans formed prior to Emperor Jimmu. This category included those whose ancestors were gods indigenous to the area (土着神) and those whose ancestors were connected to gods descended from Heaven (天孫) prior to Emperor Jimmu. There are 326 groups originally from China or Korea recorded as descendants of foreigners. In addition, there are 117 clans in the Register not belonging to any of the three categories owing to unclear origins. The Register records that out of 1,182 family names in the capital and its surroundings, 326 names, approximately one-third, originated from China and Korea. This shows how many elites in the capital area came over from China and Korea and hints at the possibility of large-scale migratory movements from the Chinese mainland and Korean peninsula to the Japanese archipelago.

In the next two sections, I will examine the clans that originated in China and Korea and that are recorded in the Register.

\subsubsection{Clans of Chinese descent}

Out of 326 clans descending from foreigners and found in the Newly Edited Register of Family Names, 163 clans are said to originate from China. They include the earlier-mentioned Hata and Aya clans, those who came from Tang and their descendants, as well as other groups that claim to have descended from the royalty or aristocracy of various Chinese dynasties. While these groups claim to be descendants of Chinese royalty, the vast majority of them came to Japan via Korea, and it is likely that many were in fact indigenous Koreans.

A common characteristic of these groups is that many adopted the names of Chinese dynasties as their family names. These clans also claimed to have descended from the dynasties that served as their surnames. Others chose to 
adopt regular Chinese family names. Most clans, however, chose to adopt Japanese-style family names much like those used by Japanese aristocrats at the time. These Japanese-style names seem to be closely connected to geographic regions in which these groups resided. Also, in accordance with the naming system of ancient Japan, each family name was followed by a kabane (姓), or hereditary title used to denote rank and political standing. Such kabane included Kimi (公), Asomi (朝臣), Omi (使主), Suguri (村主), Muraji (連), Miyatsuko (造), Obito (首), Imiki (忌寸), Sukune (宿襧), Fubito (史), Kusushi (藥師), and Eshi (画師).

Clans of Chinese descent recorded in the Register are the following: Hata (秦), Hatahito (秦人), Uzumasa (泰秦), Hatago (秦子), Ayahito (漢人), Fumi (文), Yako (楊胡), Yako (楊侯), Kura (内蔵), Hirata (平田), Sakanoue (坂上), Ôtomo (大友), Sakurano (樱野), Kuwabara (桑原), Tsukushi (筑紫), Takaoka (高岡), Nagaokaimiki (長岡), Kochi (己智), Nakamura (中村), Ôishi (大石), Nishikiori (錦織), Hinokuma (檜前), Matsuno (松野), Tanabe (田邊), Oyama (大 山), Takamuku (高向), and Hafuribe (祝部). The list also includes groups who came to Japan from Tang and whose family names changed: $\mathrm{Li}$ (李) $\rightarrow$ Kiyomune (清宗), Shen (沈) $\rightarrow$ Kiyomi (清海), An (晏) and Xu (徐) $\rightarrow$ Sakaeyama (㮡山), Zhang (張) and Meng (孟) $\rightarrow$ Suse (嵩山), Lu (盧) $\rightarrow$ Kiyokawa (清川), Ma (馬) $\rightarrow$ Niioki (新長). This shows that by the early ninth century, when the Register was published, foreign groups that immigrated to Japan were changing their family names into Japanese-style surnames.

\subsubsection{Clans of Paekche descent}

There are 104 clans of Paekche descent recorded as descendants of foreigners in the Newly Edited Register of Family Names. Here are just some of the 104 family names: Kudara (百済), Yamato (和), Tsuki (調), Hayashi (林), Kaguyama (香山), Hirota (廣田), Asukabe (飛鳥部), Sugano (菅野), Kazurai (暮 井), Miyahara (宮原), Tsu (津), Funa (船), Takano (高野), Sakata (坂田), Fuha (不破), Ka (賈), Kinunui (衣縫), etc. These family names were written alongside the kabane, in accordance with ancient Japanese custom. Some of the kabane of Paekche-descended clans include Kokishi (王), Kimi (公), Asomi (朝臣), Omi (使主), Suguri (村主), Muraji (連), Miyatsuko (造), Obito (首), Sukune (宿襧), and Fubito (史). In the case of clans of Paekche origin, a few clans of royal blood adopted the name of their state, Paekche, as their family name. Most, however, adopted regular Japanese-style surnames instead.

\subsubsection{Clans of Koguryŏ descent}

There are 41 clans of Koguryŏ origin listed as descendants of foreigners in the Newly Edited Register of Family Names. A few of those 41 family names include Koma (高麗), Koma (狛), Ôkoma (大狛), Kô (高), Ô (王), Sena 
(背奈), Toyohara (豊原), Takata (高田), Kifumi (黄文), Kuwabara (桑原), Yasaka (八坂), Torii (鳥井), etc. The kabane found alongside these family names include Kokishi (王), Kimi (公), Asomi (朝臣), Omi (使主), Suguri (村主), Muraji (連), Miyatsuko (造), Obito (首), Sukune (宿襧), and Fubito (史). Members of the royal family adopted their country name as a surname, while other clans used the same family names they had in Koguryŏ. Most clans, however, adopted regular Japanese-style family names.

\subsubsection{Clans of Silla descent}

Out of the 326 clans listed as descending from foreigners in the Newly Edited Register of Family Names, 8 clans are classified as descendants of Silla people. They are the Tachibanamori (橘守), Miyake (三宅), Toyohara (豊原), Unabara (海原), Maki (真城), Itoi (糸井), Fushimaru (伏丸), and Hine (日根). In accordance with Japanese custom, these family names are followed by kabane such as Muraji (連), Miyatsuko (造), and Fubito (史). There is a hierarchy among kabane, and clans originally from Silla, it is interesting to note, did not possess high-level kabane. None of the clans from Silla adopted their country name as their family name. This seems to be because no member of the Silla royal family had settled in Japan at that time. All clans from Silla adopted Japanese-style family names. Among them are four clans that claim to be descendants from Amenohiboko (天日槍), the mythical Silla prince said to have come to Japan.

\subsubsection{Clans of Kaya descent}

Out of the 326 clans descending from foreigners and listed in the Newly Edited Register of Family Names, 9 clans are classified as Kaya descendants. They are the Michita (道田), Ōchi (大市), Shimizu (清水), Tatara (多多良), Hirata (辟田), Ōtomo (大伴), Toyotsu (豊津), Karabito (韓人), and Arara (荒荒). Following Japanese custom, these family names are followed by kabane such as Kimi (公), Muraji (連), Miyatsuko (造), and Obito (首). All the clans from Kaya adopted Japanese-style family names. Among them, 3 are said to be descendants of Tsunugaarashito (都怒我阿羅斯等), the mythical Kaya prince that came to Japan.

\subsection{Foreign Family Names in Ancient Japanese Naming Systems}

In ancient Japan, uji (氏) referred to blood-related groups, whereas kabane

(姓) was a hereditary title indicating the status of one's family or the occupation of a powerful clan. In ancient China, xing (姓) referred to blood-related groups, and shi (氏) indicated a hereditary occupation - the opposite of Japan.

Around the fifth century the ancient Japanese state was in the early stages of development, and it was while the Yamato court was establishing its rule 
over Japan that family names became established and systematized. The court bestowed uji and kabane on elites in the capital and powerful families elsewhere in the country according to their contribution to the Yamato regime, and these subsequently became hereditary. Most of these uji and kabane seem to have originated from geographic and occupational names. During the expansionary period of the late seventh century, there were eight kabane enacted into law-Mahito (真人), Asomi (朝臣), Sukune (宿襧), Imiki (忌寸), Michishi (道師), Omi (臣), Muraji (連), and Inagi (稲置) —and a system of surnames became firmly established. Even commoners (良民) came to have uji.

As the older uji-kabane system collapsed in the mid-Heian period, kabane became increasingly uncommon. Myōji (名子, 苗子), an appellation representing specific families, began to be used, and was fully adopted by the ruling class by the early medieval period. After the Meiji Restoration brought an end to feudalism in 1868, anyone in Japan could use a myōji. Myōji can be seen as a more progressive successor to $u j i$.

If we compare the formation of family names in Japan with that of Korea, the most significant characteristic is that Japan did not adopt Chinese-style family names despite using Chinese characters. This difference influenced how family names developed in each country. In Korea, the use of Chinesestyle surnames encouraged people to locate their putative apical ancestors in China, and in this process, many clans came to claim Chinese ancestry. Hence, we cannot view the putative apical ancestors of Korean clans of foreign origin as accurate reflections of population movements from China to Korea. In Japan, however, people did not adopt Chinese-style family names, and so families did not tend to link putative apical ancestors to China for the most part.

The Newly Edited Register of Family Names, published during the expansion of the uji-kabane system, records several characteristics of Japanese family names. A third of the 1,182 clans in the Register originated from outside Japan. Some of these groups adopted their country names as family names, while others took Chinese-style surnames, but the vast majority of clans of foreign origin used regular Japanese-style family names. This demonstrates that by the early ninth century, the Japanese system of surnames had developed into an institution different from that of the Chinese. The Register also classified its 1,182 clans into three groups: descendants of the imperial line, descendants of the gods, and descendants of foreigners. Clans were descended from two types of ancient gods: gods descended from Heaven (天孫) and indigenous gods (土着神). In the Register, the descendants of such indigenous gods had higher social standing than the descendants of foreigners, and this shows that the Japanese valued the indigenous over the 
foreign. This linkage with the gods is similar to how ancient Korean royal families created new Chinese-style surnames by linking them to state foundation myths.

The fact that the Japanese did not adopt Chinese-style family names and instead linked their origins to indigenous myths and gods suggests that Japan did not experience the Sinicizing tendencies of Korea. Hence, the claim that one-third of the clans recorded in the Register originated from China and Korea is likely a reflection of reality, not of a mindset or ideology. Of course, many elite lineages contain records that one suspects are highly embellished. However, in view of the large-scale migrations from Korea and China to Japan between the fourth and seventh centuries, the large number of clans with foreign origins recorded in the Register is no exaggeration.

In Korea, people adopted Chinese-style family names, and their Sinophilia created a tendency to link their putative apical ancestors to China. In contrast, in the case of ancient Japan, elites tended not to fabricate connections between their putative apical ancestors and China or Korea due to a similar mindset that strived to imitate Chinese or even Korean practices. The ancient Japanese strongly admired Chinese culture and enthusiastically received this culture by sending envoys to the Sui and Tang dynasties. However, as Japan was geographically distant from the Chinese mainland, direct contact with Chinese dynasties was comparatively rare. They also culturally admired Korea, and Korean immigrants to Japan played important roles in ancient Japanese history. But with regard to Korea, Japan felt not only admiration but also a competitive spirit, which created a tendency to view Korea as a tributary state of Japan, as seen in the Chronicles of Japan. Within this context, the practice of fictitiously linking putative apical ancestors to China or Korea was unlikely to take root in Japan.

\section{Conclusion}

In this discussion I explored family names of foreign origin in premodern Korea and Japan. I conclude with the following seven points.

- The formation of family names in Korea and Japan show great differences. In Korea, family names came about with the introduction of Chinese culture and Chinese characters, and Chinese-style family names were adopted. While the Japanese were also influenced by Chinese culture and employed Chinese characters, they assumed indigenous family names.

- In the process of adopting Chinese-style family names, ancient Korean rulers linked putative apical ancestors with state foundation myths and formed new surnames. This shows that Korean rulers did not perfunctorily imitate Chinese surnames, but rather independently developed new ones. 
- Independent development can be seen among Korean elites as well. They used their given names, tribal affiliations, myths, and legends to form new surnames that were not mere imitations of those used in China.

- By the beginning of the Koryŏ period, the use of family names had disseminated throughout the ruling class, and in the early Koryŏ, Chinese-style family names were adopted by the masses as well. Many Korean family names did in fact historically originate from Chinese apical ancestors. However, many clans also made up historical ties between China and their putative apical ancestors because they were using family names found in China. Korean Sinophilia no doubt encouraged this phenomenon.

- Despite numerous Korean clans that claim Chinese origins, the most populous clans today are those indigenous to Korea. Clans of foreign origin that formed between the late Koryŏ and Chosŏn dynasties - in other words, clans that definitely came from the outside - are rare, and their numbers are comparatively few today. This shows that Koreans preferred indigenous family names over foreign ones, and that indigenous family names were widely propagated.

- Because ancient Japanese elites did not adopt Chinese-style surnames, and because they traced their origins from mythical gods, the Japanese likely did not seek to link their putative apical ancestors with China in the process of forming family names. Hence, the clans of Chinese and Korean origin that make up one-third of the 1,182 clans found in the Newly Edited Register of Family Names are likely to be realistic reflections of historical migrations from abroad.

- Koreans adopted Chinese-style family names and traced putative apical ancestors to China. This practice was further encouraged by Korean Sinophilia. In the case of Japan, however, Japanese clans lacked similar admiration for Chinese or Korean culture and so did not trace their origins to China and Korea.

\section{References}

\section{Chinese works}

He Xiaoming 何晓明. Xingming yu Zhongguo wenhua 姓名與中国文化 (Family Names and Chinese Culture). Beijing: Renmin Chubanshe, 2001.

Ji Xiuqin 籍秀琴. Zhongguo xingshi yuanliushi 中国姓氏源流史 (The History of Origin of Chinese Family Names). Taipei: Wenjin Chubanshe, 1997.

Wu Shenghui 巫聲惠. Zhonghua xingshi dadian 中華姓氏大典 (Compendium of Chinese Family Names). Shijiazhuang: Hebei Renmin Chubanshe, 2000. 


\section{Korean works}

Ch'oe Tŏk-gyo 최덕교 and Yi Sŭng-u 이승우. Hanguk sŏngssi taegwan (An Encyclopedia of Korean Family Names). Seoul: Ch'angjosa, 1985.

Kim Chŏn-ho 김정호. Hangukŭi kwihwa sŏngssi 한국의 귀화성씨 (Foreign Family Names in Korea). Seoul: Ch'ishiksanŏpsha, 2003.

Kim Chŏn-yŏn 김정현 . Hŭnghanŭn sŏngssi, sarajin sŏngssi 흥하는 성씨 사라진 성씨 (Prosperous Family Names and Declining Family Names in Korean History). Seoul: Chosun Ilbosa, 2001.

P'yŏn Hong-gi 편홍기. Hangukŭi sŏngssi palsaengsa mich'ssijobyŏlinmlsa 한국의 성씨발생사 및 씨족별인물사 (Histories of the Origins of Korean Family Names and Clans). Seoul: Yanghyŏnje, 1999.

Sŏ Hae-shuk 서해숙. Hangukŭi sŏngssiwa sinhwa 한국의 성씨와 신화 (The Origin of Korean Family Names and Myth). Seoul: Minsokwon, 2005.

Yi Ki-baek 이기백, ed. Chokboga malhanŭn Hanguksa: Hanguksa simin kangjwa 족보가 말하는 한국사: 한국사시민강좌 (Genealogies in Korean History: The Citizens' Forum on Korean History), no. 24. Seoul: Iljogak, 1999.

Yi Su-gŏn 이수건. Hangukŭi sŏngssiwa chokbo 한국의 성씨와 족보 (Korean Family Names and Genealogies). Seoul: Seoul University Press, 2003.

\section{Japanese works}

Araki Ryōzō 荒木良造. Seimei no kenkyu 姓名の研究 (A Study of Japanese Names). Kyoto: Bunmeidō, 1929.

Maenosono Ryōichi 前之園亮一. Kodai no sei 古代の姓 (Ancient Japanese Family Names). Tokyo: Yosikawa Kōbun Kan, 1976.

Nihon seishi kakei sōran 日本姓氏家系総覧 (General Handbook of Japanese Family Names and Genealogies). Tokyo: Shin Jinbutsu Ōraisha, 1991.

Ōta Akira 太田亮. Seishi to kakei 姓氏と家系 (Japanese Family Names and Genealogies). Tokyo: Sōgensha, 1941.

Saeki Arikiyo 佐伯有清. Shinsen shōjiroku no kenkyu 新撰姓氏録の研究 (A Study of the Newly Edited Register of Family Names). Text and research volumes. Tokyo: Yosikawa Kōbun Kan, 1962-1963.

Ueda Masaaki 上田正明. Kikajin: Kodai kokka no seiritsu o megutte 帰化人: 古代 国家の成立をめぐって (Naturalized People in Ancient Japan: On the Establishment of the Ancient Japanese State). Tokyo: Chūō Kōron Sha, 1965. 